\title{
GIRLS' EXPLOITATION IN THE TRIPLE BORDER AMONG ARGENTINA, BRASIL AND PARAGUAY: BETWEEN COLONIALISM AND HUMAN RIGHTS NARRATIVES
}

\author{
MARIA CECILIA ZSÖGÖN ${ }^{1}$ \\ ${ }^{1}$ University of Buenos Aires, Pres. José Evaristo Uriburu 950, C1114, Buenos Aires, Argentina. ORCID: \\ 0000-0002-6888-2789, Email: Cecilia.zsogon@gmail.com
}

ABSTRACT: This article focuses on the narratives and underlying ideologies that enable the persistence of girls' sexual exploitation in the region of the Triple Border among Argentina, Brazil and Paraguay, where field work was conducted. We argue that the persistence of colonial practices has contributed to the reproduction of subalternity positions for girls and women - especially from impoverished sectors - enforced by the conservative and patriarchal discourse present in many countries of the region. This scenario enables the persistence and naturalization of certain practices that became "invisible" or even accepted and justified as being "cultural". In this sense, we propose that human rights narrative, although being a Eurocentric construction, can comprise a platform for raising issues on gender inequality and all forms of violence and exploitation taking place in the peripheral regions of the world.

KEYWORDS: girls' sexual exploitation, human rights, Triple border, discourse analysis

\section{INTRODUCTION}

The primary goal of this article is to examine the underlying ideologies that enable the persistence of girl's sexual exploitation in peripheral regions of Latin America. We highlight the potential of Critical Discourse Analysis (CDA) as an approach that can help us understand this ideologies and the role they play in the reproduction or resistance against dominance and inequality, since, as Van Dijk (1995) states; CDA 
attempts to uncover the discursive means of control and social influence; along with an oppositional stance against the powerful.

The conservative discourse has gained prominence since the Latin American "turn to the right" expressed in the neoliberal tendencies of current administrations. Worldwide, these phenomena can be compared to the waves of totalitarian and conservative governments that support right-wing anti-gender politics, which have contributed to reinforce children's and women subaltern position, in line with colonial and patriarchal logic.

As Odrowaz-Coates (2019) states in the introduction to this work, discourses inform preferences, behaviors and preferences towards positioning of individuals in society, based on their respective gender and their individual status. Conservative orientations may be linked or allow the mechanisms of reproduction of gender power relations and the positioning of children according to power distribution in society.

Faced with this, feminist movements such as "Ni Una Menos" [1] ("Not One Less") have proliferated in Argentina and other countries of our region. However, the rates of violence, which involves domestic violence, homicides, rapes, exploitation and even the gap in wage disparity and access to the labor market, continues to be significant. According to the UN, Latin America is the deadliest region of the world for women. There, more than nine women are killed daily, victims of gender violence, making it the most violent area in the world for women outside a context of war.

This article focuses on the political, discursive and ideological aspects that cross girls' sexual exploitation in the Triple Border Region (TBR) between Argentina, Brazil and Paraguay. We argue that conservative and patriarchal discourses enable their reproduction, since they are ideological constructs that conceal the subaltern -material and symbolic- position of girls and women. Added to that, we propose that human rights could overtake these narratives since they constitute a platform from which to address and revert issues such as violence, exploitation, gender and age inequality and other problems faced by girls in impoverished peripheral regions of the world. In order to do so, this work is structured as follows: the first section briefly describes legal framework referring to commercial sexual exploitation of children, specifically the international treaties and conventions incorporated in the normative corpus of Argentina, Brazil and Paraguay, since they are the countries that constitute the Triple Border Region. This racconto shows the relevance of child labour and exploitation in human rights international agenda that nowadays seems to collide with the proliferating conservative discourses, and even hate speeches towards women rights and gender equality. Next, we analyze the specificity of the material anchorage since we believe it conditions the forms that acquire certain practices, making it possible for instance, the trafficking of persons due to the "porosity" of the national frontiers in the region. Afterwards, we outline the forms of exploitation of girls and women in the aforementioned Triple Border, especially commercial sexual exploitation, considered a serious violation of human rights. Although this form of exploitation is not the only one, we focus on it due to its prevalence across the region and the gender bias that enables its continuity sheltered by conservative and patriarchal discourses. Following that, we address sexual exploitation of girls as described by former members of 
a program aimed at reversing these crimes in the region. The program was finally dismantled, due to -in part- the way it began to operate and uncover the powerful networks that hide behind crimes such as trafficking for sexual or labor exploitation. These narratives show that girl's exploitation is represented as some sort of "natural" or "cultural" (being almost synonyms here) phenomena as if they were the only possible life trajectory for impoverished girls of these regions.

Finally, we discuss the potential of the human rights narrative in these peripheral contexts, since they are a Eurocentric construct. Nevertheless, we argue that the very possibility to address this practices supply evidence of the value of human rights narratives - as a platform for raising issues on gender, violence, exploitation and other issues- since "it is impossible to name human rights violations in the absence of human rights norms and standards” (Baxi 2007: 189).

\section{METHODOLOGY}

In order to approach the underlying symbolic and political struggles that shape child labour and exploitation in this peripheral region of Latin America we combine research field work with critical discourse analysis around gender and conservative discourses. The research was conducted in the Triple Border Region between Argentina, Brazil and Paraguay between 2013 and 2016 [2]. The field work took place in the main cities that make part of the region: Puerto Iguaçu in Argentina, Ciudad del Este in Paraguay and Foz do Iguaçu in Brazil. Participant observation and interviews were conducted in public schools, hospitals, social welfare offices and homes for children. Here we present some observations concerning sexual exploitation as they were registered throughout the field research.

The analysis is framed within Critical Discourse Analysis (CDA), as described by Fairclugh et al (2003). As Van Dijk (1995) addresses, CDA can help us understand how the forms of inequality are expressed, legitimated or reproduced in texts (all kind of texts), by dominant elite groups or institutions who use and abuse their power through a display of different discursive structures.

Finally, any phenomenon that takes place in a trans-border region must be address considering its transnational anchoring, therefore the emphasis on the regions and the particularities that enable children exploitation. Frontiers constitute material but also epistemological borders that forced us to rethink the meaning of many categories and to verify the need for creative thinking in spaces that escape the contours established by the academy. These frameworks will help us provide a better understanding of the persistence of violence and exploitation of girls and women in a peripheral region of the world-system [3], and interpret how this practices and narratives are inserted in the dense social and political processes that cross the region.

\section{RESULTS}

The basic postulate that arises from our research is the validity of the idea that the coloniality of power persists after formal decolonization (Quijano 2000). Coloniality, as 
constitutive of our peripheral region, seems to have similarities, or to fit in the ideology of the conservative discourse, which addresses girls and women from a perspective that enables the continuity of exploitation due to their assigned -subaltern- position in society. In this context, sexual commercial exploitation can be regarded as the corollary of a trajectory signed by the deficiencies and indifference of public institutions, especially those operating at a national level (in the capital of each country). Among other reasons, we highlight the deficiencies of educational and sanitary infrastructure, the lack of social policies, and ultimately, a system that reproduces oppressive and exploitative conditions affecting impoverished women and children in peripheral regions of the world, which continue to provide cheap workforce, as well as women and girls who are addressed as highly sexualized-objectivated subjects.

Field work conducted in the region demonstrates that the interests that operate covering up these crimes have primacy over current human rights treaties, and over any other consideration that transcends the strictly monetary. Field work also shows that the extension and distinctiveness of these practices is not sufficiently documented in the Triple Border. Here again a strain for policy makers is the lack of updated data that account for the real magnitude of child exploitation, which leads to the impossibility to conduct a fair diagnosis. This vacuum is due to several causes, being one of the main the power relations that cover the occurrence of these phenomena. In cases such as the worst forms of child labour and trafficking obvious difficulties arise for their study due to their clandestine nature and the powerful monetary and politic interests that enable their reproduction. This is linked with certain dynamics of the region that allows the reproduction of exploitation in all its forms; one of the main features of the TBR is its "porosity", which enables an intense circulation of persons and goods that do not always occur within the legal frame. In this region, state limits seem to be rather abstract due to highly interconnected urban spaces. The faint limit between legal and illegal practices, and the rather precarious articulation between institutions of the three countries, set up a privilege scenario for trafficking of persons for either sexual or labour exploitation.

On the empirical level, it became clear that the subjectivity of children is rarely apprehended in adult discourse. The actions implemented are limited to "harm reduction" programs that in the long term tend to reproduce those same conditions that they should seek to reverse. In this sense, the convergence of child labour and exploitation in the social, economic and cultural fabric of the region requires actions that tend to reverse the naturalization and invisibility and, in the case of the worst forms of child labour and exploitation, arise consciousness around the fact that they do constitute serious crimes and such be addressed as such.

In a context signed by poverty and inequality, we highlight the instituting power of children's rights treaties as the materialization of a power struggle for the imposition of "meanings". The analysis of the legal frame is fundamental since laws are the result of negotiation processes for obtaining legitimacy from certain narratives; they constitute "true and important symbolic struggles" (Segato 2006). In line with this position Bourdieu addresses that the law not only regulates certain practices, but also gives status to social groups whose rights it recognizes, establishing their existence from 
the "mere act of nomination" (Bourdieu 1989: 238). We are aware that the passing of a law does not necessarily imply a social commitment to its enforcement; however, it provides a valid platform for addressing social demands.

On the other hand, this legal recognition does not lack contradictions: as Pecheny states: "the very language of human rights generates this tension: while speaking in terms of rights allows for these struggles to be heard and incorporated in the legislative agenda, doing so also implies boxing them inside the institutional frameworks of (neo)liberal democracies" (Pecheny 2009: 459). Finally, it is important to avoid both celebratory and paternalistic narratives concerning child labour, and as for its "worst forms" the need to conduct further research to understand, address and explain how forced labour has become, once again [4] an issue on international relations and in human rights narratives and politics.

\section{DISCUSSION AND DATA}

\section{Legal framework and human rights conventions concerning exploitation}

The International Labour Organization (ILO) defines commercial sexual exploitation of children "as the exploitation by an adult with respect to a child or an adolescent - female or male- less than 18 years old; accompanied by a payment on money or in kind to the child or adolescent (male or female) or to one or more third parties" (ILO/ IPEC) [5]. ILO also considers this form of exploitation as an abhorrent violation of the human rights of children and adolescents and a form of exploitation similar to slavery and forced labour.

Commercial sexual exploitation in children includes the use of girls and boys in sexual activities remunerated in cash or in kind - commonly known as child prostitution - in the streets or indoors, in such places as brothels, discotheques, massage parlors, bars, hotels, restaurants, etc; the trafficking of children and adolescents for sex trade; sex tourism; the production, promotion and distribution of pornography involving children and the use of children in sex shows (public or private) [6].

Similarly, the Stockholm Declaration adopted at the World Congress against Commercial Sexual Exploitation of Children (1996) defines the commercial sexual exploitation of children as "a form of coercion and violence against children (that) amounts to forced labour and a contemporary form of slavery," while the UN Protocol to Prevent, Suppress and Punish Trafficking in Persons, Especially Women and Children (the Palermo Protocol) defines the term "exploitation" to include "the exploitation of the prostitution of others or other forms of sexual exploitation, forced labour or services, slavery or practices similar to slavery, servitude or the removal of organs" (ILO).

In line with the above, the 2006 Report of the Independent Experts for the United Nations Study on Violence Against Children also recognizes that the exploitation of children under 18 in prostitution, child pornography and similar activities constitutes violence. Equal importance has ILO Convention 182 on the Worst Forms of Child labour, that includes slavery or slavery-like practices; the sale and trafficking of children, debt servitude, the status of "servant", forced or compulsory labour and the use of children in armed conflict. It also covers the recruitment and use of children for prostitution and por- 
nography; and for the production and trafficking of narcotics. According to ILO (2002, 2006) "they are all those jobs that, due to their nature or the conditions in which they are carried out, can damage the health or safety of children, and work that endangers their physical, mental or moral development”. Such forms can be also assimilated to the notion of "modern slavery", as they are described in the 2014 Protocol on the Forced Labour Convention.

Some figures that account for the global scale of trafficking in persons estimate that it generates annual revenues of more than 32 billion US dollars worldwide; in Latin America and the Caribbean alone, it captured 100,000 victims during 2008, according to a survey by ILO (2002) According to UNICEF, some two million children between the ages of five and fifteen are introduced annually into the sex trade worldwide. The phenomenon of child sexual exploitation, in recent years, has also increased in Latin America, due to economic and socio-cultural factors among which ILO (2002) highlights the lack of education and economic opportunities, the relatively high benefits they believe they will obtain, the cultural obligation for children to help their parents by earning money through any activity and the "disintegration" of families.

However, these factors should not ignore that the persistence of commercial sexual exploitation is due to the existence of a demand that is even greater in the tourist centers of "developing" countries, as evidenced by research carried out in the region (UNICEF 2005, ILO 2005, IOM 2010, Cilleruelo 2008).

\section{The Triple Border: Inequality and poverty in the periphery of the world system}

Social phenomena acquire a particular dynamic according to the geographical context in which they take place, in this sense we argue that the Triple Frontier between Argentina, Brazil and Paraguay enables dynamics that allow the persistence of the so-called worst forms of child labour alongside with exploitation. In this sense, we believe that the approach of the theoretical perspective of the world system, as mention above, is appropriate. The categories of center and periphery account for the operation of the capitalist system and the mechanisms through which the centers continue to exploit and expropriate the resources of the peripheries, against orthodox visions that believe that the benefits of economic development would have a positive impact on the peripheries.

In a system whose objective is to maximize profit through the difference between labour and raw material costs and the exchange value of a product, poverty, disease, malnutrition, lack of access to drinking water, basic adequate sanitation, among other shortcomings, are a constant. The inhabitants of the impoverished regions are the counterpart of the prosperity of a minority; according to Jeffrey Sachs, eight million people die each year "because they are too poor to remain alive" (2005: 29).

In this work and in line with the above, we consider that poverty and exclusion are intrinsic to the logic of a market economy. This proposal corresponds to the postulates of dependency theory and to Karl Marx's proposal about the need for a "reserve industrial army": a nucleus of unemployed that enables cheap and flexible workforce to keep wages low and perpetuate the necessary conditions for the reproduction of 
capital.

Although this may appear to be obvious in the peripheral regions, diversity of views on the Triple Border coexist, embodied in the media and technical and academic reports, each of which builds a discourse about the region that tends to emphasize its unity and harmony, or its fragmentation and conflict. Beyond the different interpretations, the area is well known for its notorious inequality, which is clearly expressed in the asymmetries between a city for tourists-consumers and another for the inhabitants of the periphery. Although exploitation, trafficking and connected crimes are typified in the regulatory frameworks of the three countries that make up the region, as well as in multiplicity of international treaties, it is a recognized route of trafficking of human beings for exploitation in neigh boring countries or even in other continents. The occurrence of these practices was not acknowledged by most of the informants, who refused to talk about the issue, on occasion out of fear since various aggressions occurred towards journalists and researchers who tried to approach these crimes.

\section{The forms of exploitation in the region}

For the purposes of this paper, we use the categories of exploitation, forced labour, slavery and worst forms of child labour as synonyms since we consider that the subtleties of each category are subsumed in the fact that they all represent violations against the very basic rights of children.

However, due to their characteristics/particularities they can be simply defined as crimes against humanity.

As for the figures, since these crimes take place with the complicity of politicians and officials of the law are very complex to investigate, the only available data consist on estimations about women and girls who fall into trafficking networks or became victims [7] of other forms of exploitation for sexual or labour purposes.

The enormous economic revenue from these practices/crimes, such as commercial sexual exploitation of children, trafficking, sex tourism and others, is recognized in the region, although their invisibility and the network of complicities that enable their persistence to make their study extremely complex. More detailed studies in conjunction with the security forces of the three countries could greatly contribute to have a reliable diagnosis that could lead to take actions aimed at reversing and preventing these crimes and take pertinent legal actions towards recruiters, intermediaries and exploiters who take advantage of the vulnerability of the victims, although here we do not think of victims in terms of individual injustice, but as an injustice "rooted in a structure of social and historical conditions that determines the situation and renders it intelligible" (Pecheny et al. 2019: 457) The physical and psychological consequences of exploitation (in all its forms), are extensively documented by multiple studies carried out by ILO, UNICEF, and other national and international organizations specialized in this problematic issue. However, commercial sexual exploitation is not the only form of exploitation, or the only one that can be part of the "worst forms of child labor", as it is typified in the above-mentioned Convention.

Other forms of exploitation with a presence in the TBR have to do with servitude 
(criadazgo), an extended practice in Paraguay but also in the Northeast of the Argentine Republic. Criadazgo refers to a form of exploitation that takes place in the private sphere of a domicile, so its detection through labour inspections is practically unfeasible. In this practice, children (usually girls, but also boys) are handed over, at ages as early as two years old, to a "caretaker" family, almost always living in cities, which will be "responsible" for their education and support it in exchange for the domestic work of the little "maid".

However, frequently this is not the way things go, and girls and boys are exposed to long hours of work, that can include cleaning, washing, taking care of the elderly or sick persons, amongst other tasks which prevents them from attending school or makes their schooling be truncated due to absences, fatigue or even the lack of school supplies and appropriate equipment to attend educational institutions. Most of the times girls come from extremely vulnerable rural environments, from large families who are unable to provide support for their sons and daughters and who may really believe that by "sending them to the city" they are giving them the opportunity to move forward in their lives through access to the education that their parents, for a variety of reasons, could not access or could not complete.

Although exploitation is conditioned by gender issues, we also consider the age variable, since girls are more exposed to suffer violence in all its forms, due to the distribution of power in our society, in which girls from impoverished backgrounds have less opportunities to access to formal education, or to complete it, even compared with boys of the same age and background, since girls are most likely to perform domestic work and other tasks associated to domestic reproduction. As Cioban discusses, these types of activities are considered by society to have a limited economic value and they are underestimated. We must also notice the gender division "between jobs undertaken by children, a fact that further marginalizes activities done by girls, which are considered as 'not so important'" (Cioban 2018: 108). These differences are conditioned by gender issues, but here we focus on the double drawback that girls go through not only because of their gender, but also because of their age, that could make them lack same tools that adult women may possess to defend themselves against certain abuses or to make their voices heard.

\section{The experience of a Program aimed at eradication of commercial sexual ex- ploitation of children}

This program, which will be addressed as "Happy Childhood" aimed at the eradication and prevention of commercial sexual exploitation of children and was operative between 2004 and 2012, financed by the Argentinean government along with an international organization. The actions were originally focused on psychological support, informative talks, and reintegration into the formal education system for victims of trafficking and sexual exploitation.

The testimonies presented in this section come from interviews with members of the Program. A former coordinator, Graciela [8], reminisces about the beginnings: "In 2004 the program was created to conduct survey about children living in the 
street, in situations of violence, victims of abuse and especially to eradicate commercial sexual exploitation of children. Those were the formal intentions. For this, a work team was formed".

The "team" was integrated by a psychologist, a teacher and a law student whom they called "our lawyer": a rather humble team if we take into account the magnitude of the objectives they pursued and the powerful interests operating to guarantee the continuity of exploitation and linked crimes.

Anyway, the planning organized in the very beginning was short-lived;

When we installed the office and said ok, we are going to start the talks [9] in the neighborhoods, we began to receive lots of complaints. So, we had to forget about the initial planning. I was very surprised because I had been a teacher for 35 years. So, I thought, I have lived for 35 years in this city, inside a bottle, because I never thought there were so many aberrations and ugly things that were committed against children.

Graciela recalls the initial frenzy, of receiving complaints, of going to the police stations, but she immediately began to glimpse the network of complicity behind a crime as lucrative as commercial sexual exploitation;

At the time there was a police officer that helped me a lot, and I think it cost him his job. Then I began to see the other side. How officials, police, authorities, who sympathized with the Program's initiative, were being fired from their jobs, left aside, reassigned... of course, it is one thing to talk about the child who is begging for coins in the street, selling pebbles [10] or whatever, and something else is to talk about sexual exploitation where tourism industry and authorities are involved...

In this context, the first threats did not take long to come, although in a veiled way, they were still "warnings".

Estela, another former member, recalls: "I was going to the crash, I was facing everybody. Then they (the authorities) told me to slow down... and then I realized that authorities themselves were the ones who come here to ask for children (for sexual exploitation). I was very distressed, I didn't sleep (...) I didn't know how to get out of it."

The first "clash" was with a minister "who was being of great help", and who told her to "stop a little" because the people of the city "were very offended". She explains the causes of this anger:

I talked a lot, I was very mediatical, I was on television every day, and I said please don't turn this city into a "sexual paradise", things like that. Because where there is a five-star tourism there is behind a very poor population with exploited people, not only children ... some taxi drivers told me about parents who gave them the phone number in case a tourist asked for a child, a girl, no matter the age, call him ... then I thought, this cannot be. Everything is wrong here. Everything.

And she adds:

It seems such hypocrisy to me... when I began to know reality, it surpassed me. 
When a new government assumed, they called us and asked not to clash with the people; instead of that, to give a lot of talks ... and we said yes, we were going to give talks. And raise awareness and raise awareness. I told children at school how the traffic works, when the police catch a drug dealer who is also a human dealer, because a kilo of marijuana is equivalent to so many girls ... then the transaction is done with zero investment, they just kidnap and take the girls.

On the role of the family and the responsibility of adults in the commission of exploitation Estela comments:

There were mothers who offered their children in exchange for drugs, because they were addicted... A 20-year-old girl who let her little girls be abused in exchange for a joint, crack, whatever... a dad who gave her little daughter for money or whatever ... the little girl was 9 years old and when we rescued her because the neighbors told me; look at that child, she is being abused by many people, I took her to the doctor and he told me that she would never have babies, because she was shattered, shattered inside and also at the level of the mind.

The narratives allow us to infer that the participants of the Program inquired more thoroughly than perhaps - tacitly - they had been "allowed" to do by political authorities. The initial idea of the Program was to give prevention workshops; however, it ended up exposing the plot of complicities of public officials and security forces, which eventually led to the dismantling of the Program.

As Graciela states:

I first made the complaints, and then I realized how silly I was, because what was I going to gain? If the commissioner himself told me; you are attacking important people. So, defense of the children, zero. Then they began to corner me from all sides, until one day a senior official told me: "there are no more contracts for you.

Despite of this, the Program formally continued. A young student was put in charge, "with very precise orders: all had to be very light, very quiet", until its definitive closure in 2012.

About raising awareness around commercial sexual exploitation, Estela comments: "I think we have to try to make people realize that a crime is being committed, that the taxi driver, who takes a girl to Brazil or Paraguay hidden in the trunk of the car to be abused on the other side, is committing a crime, that is being involved (as an accomplice). People need to see that, but they never understood these practices constitute severe crimes. They think impoverished girls are there for that: to be abused, to be raped, and in return, give them some coins”.

It is worth noticing in the fragment the representation of social actors, since their inclusion or exclusion in the discourse is quite significant, as Fairclough (2003) points out, there are many motivations for exclusion, but "this may be politically or socially significant" (Ibid.: 149). In this case, the exclusion of the kidnapers/recruiters/exploiters in the discourse mirrors the way impoverished girls are represented in social imaginary, as if sexual exploitation was "something which happens to people rather 
than something which is done to people-a calamity rather than a crime" (Ibid.: 149). This absence of the perpetrators contributes to place the blame in the victim, rather than in the criminals, which is a symbolic way in which patriarchal and conservative discourses conceal these practices.

As for the places of destination,

Sometimes they convince the girls and took them to Buenos Aires, with a false job offer... or to the south, many girls went south. The majority returned with babies, (product of abuse)... A 12-years-old girl was given a brutal beating because she did not want to prostitute herself and ended up in hospital. There the doctor realized that the 18-year-old document had nothing to do with the physical structure of the little girl who was in the hospital.

Another case that highlights the multiple logics that cross these crimes and enable their persistence had to do with three little sisters who were taken to Buenos Aires:

When I reported a mother, who took her three daughters to a brothel (prostibulo), they (the lawyers) told me “it can't be true”. But yes, it was. The mother took them to a prostíbulo in Buenos Aires. I had to go from Misiones [11] province for the trial and this time I got really mad at the judge (...) one of the little girls was my first-grade student, now she was 16 years old. She was taken by her own mother who told her that she was going to work as a babysitter but instead she locked her in the brothel and said here you will do what I tell you. The owner of the brothel, who was indicted, had taken these girls as his "wife", he tattooed her arm with his name, took her to some tourist places and so on. So, the (female) judge of the cause tells me, well I didn't see her sad and crying in the photos, she was very smiley. But when this same girl came to see me, she was really distressed and in panic. But the judge told me: you are only a teacher. How can you define the panic situation if you are not a psychologist?

And the same judge added: "In Puerto Iguazú you put little girls to dance at the carnival" (as if implying that they want to be abused, or that if this happens, it is their fault, the victims' fault, as pointed out above).

To which Graciela responds:

Listen to me; they are customs of a population that girls dance at the carnival. That is, that macho thought ... and I saw the face of the other (male) judge, who was surprised that the woman judge attacked me. I thought about hitting in her face, but I didn't want to go to jail. So, because this girl was poor, because she was smiling, is she doomed?

We can see this fragment in terms of a maybe rather unconventional gender discrimination, since this attitude comes from another woman, even worse, a representative of the law (in the figure of the judge), who assumes that girls who take part in certain social practices (Carnival, here) shape their trajectory since they voluntarily expose as potential victims of sexual exploitation.

As a corollary: 
She (the girl) returned (to her home in Iguazú) because she learned that recruiters were coming to take her little sisters, of 11 and 14 years old. As a result of the trial, the mother of the girls was given house arrest; the kidnapper was sentenced to ten years in jail. As for the police officer who collaborated with this cause and many others on sexual exploitation of children, he was dismissed from the force. They just fired him... It's like I'm carrying a backpack full of people thrown away, pushed out, left aside... but I think we're all adults and we all knew there would be consequences.

The dialectic of the previous fragment highlights many aspects of patriarchal and conservative discourse, specially the fact that those -male or female- who try to act within the legal framework expose themselves to be dismissed, or, in this region and due to the crime we address, to be threatened, or worse.

Finally, the main defender of this girl was not the law or any other institution, but it was herself, who returned home to protect her younger sisters. This clearly shows not only the inaction but also the complicity of the actors who supposedly should defend children against exploitation and all kinds of abuse. But it also shows the agency of children, their capacity to make their own decisions, and in this case, protect her little sisters when all the system and even her mother, failed to do so.

Other aspects that contribute to the complexity of these crimes relate to the consent of the victims [12], informants mention that sometimes they claim to have offered themselves "voluntarily". But once they were taken to the first destination, the recruiters would take away their identity document (ID) and they knew "that leaving the brothel or going to the police would be of no use since nobody would believe them. In addition, they threaten them with their families since the recruiters knew where they lived".

Some examples of recruitment through deception, and the consequences of these actions on the girls, on their families and even on the members of the program are mentioned by Graciela:

A girl told me: I went to Buenos Aires because they (the recruiters) told me I was going to be a bar tender. Can you imagine? A young girl from the villa, she didn't have much of an idea. They told her she could go with her four-year-old daughter. The first thing they did was to take the little daughter away. Then she had no choice but to accept everything, because her daughter's life was at risk. They do whatever they want. We recovered this girl because his brother contacted me, and with a friend commissioner we went to this brothel...The little girl is now 10 years old and is undergoing psychological treatment, because she remembers. She remembers what happened to her and her mother when she was 4 years old.

Estela adds "we had cases of girls of 13 years old; they promised that they would be able to buy a car, to buy fancy clothes. You have to make them -the girls- understand that what they are doing is wrong, that it is a crime, that they are going to be exploited, abused. Many times, the girls felt that we ruined their future (by saying these things). Another girl was going to Buenos Aires, the father made the complaint that she was being kidnapped and she said "no, no, no, I'm going to get married". And when the 
Gendarmerie took her off the bus, she felt that I had ruined her life. We won many enemies also among the victims".

I asked Estela if the girls were warned about the risks to which they exposed, because in this socioeconomic system, victims seem to be more accountable or responsible for their situation than abusers for committing these crimes.

Her answer:

We explained, did a lot of workshops and talks. But at the moment they do not understand. They think it is their opportunity to improve their lives. Their place of origin is very humble, with many needs. Although there are schools in all neighborhoods in this city...But when you find out that a 14-year-old girl ran away with a truck driver who promised that she would dance in an (Argentinean well known) television show there you say, everything is possible. Everything. Instead, he took her to another province, where she was exploited and later rescued. She thought she was going to dance in a television show. There are things that...how do you handle them? Because that's a magnet, it's an attraction. To dance, to be famous.

The closure of Happy Childhood program accounts for the double standard with which some highly sensitive problems such as trafficking for sexual and labour exploitation are handled. Although concern is expressed at the discursive level, actions that have a certain impact and can contribute to preventing or reversing the consequences of these crimes are finally dismantled as they conflict with powerful interests that allow and require the continuity of these practices.

Fallen by the wayside are the physical and psychological integrity of the victims, the work and even the lives of many officials who tried to do "the right thing" and the frustration of those who dedicated their time and training to attempt to reverse the plots of power and complicity, with all the risks it involved. About fear and threats, Estela comments that "at any moment a stranger could insult you or beat you up. This is difficult because you have everything against you, everything."

During the interviews conducted on my field work, the reluctance of many informants (especially politicians and security forces) to answer questions about these issues was evident, so I asked Graciela if the official strategy was denial. She answered:

Total denial. To talk about this is to attack tourism, against the city. It is a bad word. It became very difficult ... in the 35 years as a teacher I was with so many children from very adverse backgrounds ... it was a preparation to face this. Because it is very hard, it is a terrible reality. A social worker told me 'you need a psychologist' and I said no, what I need is justice. I need justice. If there were justice none of this would happen. But things keep happening.

These fragments account for the way discourse functions not only to "disguise, emphasize and legitimate, social position and hence power of speakers, but also to control the minds of recipients in desired ways" (Van Dijk 2005:18). All of this in the interest of the powerful and against the interests of the less powerful. And here, we believe, lays the potential of discourse analysis for revealing these relations of power, 
dominance and inequality.

\section{CONCLUSIONS}

\section{Colonial and conservative discourse: all roads lead to Rome}

Specialized agencies construct discourses and narratives based on a Eurocentric conception [13] of childhood and family. But in Latin America things did not develop in the same way as they did in the central regions: "while in Europe children received an increasing pedagogical and medical attention, family and school, the children of the European colonies, converted like their parents into subordinates, entered the productive circuits of servility and slavery" (Pedraza 2007: 83). Likewise, European children were gradually freed from work and families became bourgeois families, education became obligatory and free and basic medical services were made available to the working classes, while children under colonial regimes continued to be part of the work resources of a world population that is racially hierarchical (Ibid.: 83).

That is, the coloniality of power appears as constitutive of our region, rather than as a consequence of the conquest and colonization of America. As stated above, in words of Anibal Quihano, coloniality of power persists after formal decolonization (Quijano 2000). Also, as Lilia Monzó states, "colonialism became and continues to provide the greatest form of hyper-exploitation, with significantly cheap labor and horrific working conditions" (Monzó 2019: 51). This process extends even after independence when the Creole bourgeoisie, elite of the new nation-states, perceived their interests as equals to those of the former European rulers. This ideological assimilation renewed the colonial character of the new nations and established social mechanisms to reproduce differences in all spheres, including the labour market and education.

For instance, as Odrowaz-Coates points out, "the initial economic and social dependencies remain in the conditions of the neoliberal, free market economy, maintaining cheap or enslaved labour in the previously exploited areas" (2017: 15).

In line with this idea, Lilia Monzó argues that "the greatest myth of our time is the notion that we inhabit a postcolonial world, that when the global south rose up against the horrors inflicted upon them by the colonial powers and victoriously proclaimed their independence, the economic, social, and political assault on the so called developing world and its people ceased but colonial relations have and continue to persist" (Monzó 2017: 15).

Coloniality -as constitutive of our region- seems to have similarities, or to fit in the ideology of the conservative discourse, which addresses girls and woman from a perspective of subalternity that enables the continuity of exploitation situations due to their assigned position in society. Domestic violence, child abuse, sexual abuse and the early breakdown of family ties are often the triggers of sexual exploitation of children. Cultural issues include the consideration of girls and women as an object and property, as Schiavoni (2003) points out, we live in a society where the patriarchal discourse and practices are much more present than we think and where men feel with the right to take women as objects.

As for children, they were not always assessed, considered, approached, or recog- 
nized in the same way. For as long as the notion of "childhood" has existed, it has frequently been equated with lacking or shortcoming. This idea has only relatively recently changed, at least in the legal aspect. But still, children are far from having a voice in our adult-centric world. Thanks to the narrative of the rights of the child, progresses have been made; however, gender inequalities persist in peripheral regions like Latin America. This gap has implications in the occurrence of many crimes whose victims are, most of the time, women and children.

In this scenario it seems difficult to think of an alternative to capitalist hegemony and the market economy, but there are interstices from which alternative proposals can be produced. And here again we highlight the importance of human rights narratives as potential tools from which recreate practices tending to reverse violence against children.

The fundamental challenge for human rights is, as Hanna Arendt argues, that despite being conceived as belonging to all humanity, from the moment of enunciation human rights only make sense within the areas of sovereignty, so refugees and stateless persons represent "the very end of human rights", expelled not only from their communities but also from humanity, what she calls "human rightlessness" (Arendt, cited by Baxi 2007). That is to say, the people who most need the protection of human rights are those to whom these rights are denied, a statement that can be extended to children in situations of vulnerability, poverty, exploitation.

Yet, human rights could be operative since they constitute a symbolic rhetoric with practical consequences, and could, as such, be incorporated in the social fabric of the triple border and reinforce actions in favour of the welfare of children in the region. A creative reading of human rights narratives could enable the conditions for the (re)appropriation of rights, and the mobilization of marginal narratives based on the specificity of Latin American societies.

We believe it is essential to rescue the theoretical, epistemological and methodological frameworks to adapt them to the new social dynamics, which requires resignifying the categories of childhood, child labour and exploitation, but also rethinking our own logic as social scientists and the way in which we could contribute to recreate practices and discourses tending to guarantee children's rights. It is necessary to face these challenges decisively and urgently to guarantee their well-being, their survival and their happiness. Finally, in line with Monzó (2019: 271) we believe that "in this world where millions of people live in dire poverty and endure unimaginable suffering and humiliation, there is still hope ad beauty and goodness".

\section{NOTES}

[1] A campaign against femicide that began in Argentina, in 2015.

[2] Research conducted for my PhD in Social Sciences (Universidad de Buenos Aires, 2017). [3] The theoretical perspective of the" world system" is based on Lenin's proposal (1916), who used the categories of center and periphery to account for the functioning of capitalism and understand the mechanisms through which the centers exploit and expropriate the resources of the peripheries. These theses were reworked 
by various authors, among whom is Immanuel Wallerstein (The modern world-system, 1992).

[4] Let us remember that ILO's Forced Labour Convention dates from the year 1930. Its full title is "Convention Concerning Forced or Compulsory Labour," and it is one of the eight fundamental conventions of the International Labour Organization.

[5] https://www.ilo.org/ipec/areas/CSEC/lang--en/index.htm

[6] https://www.ilo.org/ipec/areas/CSEC/lang--en/index.htm

[7] Although we do not feel very comfortable with this term, we believe that girls who suffer abuse and exploitation can be regarded as "victims" in many levels. First, victims of a system that was not able or willing to guarantee their rights to safety and their integrity, nor to provide opportunities for their development. Second, a legal, cultural and economic frame that enables recruiters, traffickers and consumers of child pornography and of child prostitution to operate with impunity and even to justify these practices based on an ideology that regards girls and women as -merely- highly sexualized objects.

[8] All names have been changed.

[9] Talks (charlas): Informal presentations about certain issues.

[10] Small semiprecious rocks taken from the nearby mines of Wanda.

[11] Misiones is the province located in the northeast of Argentina and it limits with Brazil and Paraguay. Puerto Iguazú, Puerto Libertad and Puerto Esperanza are three of the main Argentinean towns of Misiones that integrate the Triple Border. The distance to Buenos Aires is about $1,300 \mathrm{~km}$.

[12] Although such consent is not considered valid within the frame of the actual legislation.

[13] "Europe" here is used as a metaphor rather than a geographical area, and refers to "everything that was established as a racial, ethnic and cultural expression of Europe, and as a extension of it, that is to say as a distinctive identity subject to the coloniality of power" (Quijano 2014: 69).

FUNDING: this work was supported by a fellowship of UNESCO/ Janusz Korczak Chair in Social Pedagogy, The Maria Grzegorzewska University, Warsaw, Poland and a fellowship of the National Council of Scientific and Technical Research (CONICET) of Argentina.

CONFLICT OF INTEREST: The author declares no conflict of interest.

\section{REFERENCES}

Baxi, Upendra. 2007. The future of Human Rights. Oxford: Oxford University Press. Bourdieu, Pierre. 1989. O Poder Simbólico. Rio de Janeiro: Bertrand Brasil.

Cioban, Smaranda. 2018. "Exploring how children perceive their work. Case study in Salaj County, Romania.” Pp. 79-118 in Children and Youth in Varied Socio-Cultural Context. Theory, research, practice, edited by U. Markowska-Manista. Warsaw: 
Wydawnictwo Akademii Pedagogiki Specjalnej.

Lenin, Vladimir. 1975 [1916]. El imperialismo, fase superior del capitalismo. Buenos Aires: Anteo.

Fairclough, Norman. 2003. Analyzing Discourse. London: Routledge.

Lander, Edgardo (comp.) La colonialidad del saber: eurocentrismo y ciencias sociales. Perspectivas latinoamericanas. Buenos Aires: CLACSO.

Monzó, Lidia. 2017. Preface in Symbolic violence in socio-educational contexts. Poland: Wydawnictwo Akademii Pedagogiki Specjalnej im. Marii Grzegorzewskiej.

Monzó, Lidia. 2019. A revolutionary subject. Pedagogy of Woman of color and Indigeneity. New York: Peter Lang.

Odrowaz-Coates, Anna. 2017. "Revisiting power and supremacy in the post-colonial world. Globalization as a refined phase of colonization.” Pp 13-23 in Symbolic violence in socio-educational contexts. Poland: Wydawnictwo Akademii Pedagogiki Specjalnej im. Marii Grzegorzewskiej.

Odrowaz-Coates, Anna. 2019. “Gender equality and children's equality in liberal and conservative discourses; Implications toward language and society.” Society Register 3(4): 7-16.

Organización Internacional del Trabajo (OIT) Convenio 138 sobre la edad mínima de admisión al empleo (Entrada en vigor: 19 junio 1976)

Organización Internacional del Trabajo Convenio 182 sobre las peores formas de trabajo infantil, 1999 (Convenio sobre la prohibición de las peores formas del trabajo infantil y la acción inmediata para su eliminación).

Organización Internacional del Trabajo 2002. Un futuro sin trabajo infantil. Informe global con arreglo al seguimiento de la Declaración de la OIT relativa a los principios $y$ derechos fundamentales en el trabajo. Ginebra: Conferencia Internacional del Trabajo.

Organización Internacional del Trabajo 2006. La eliminación del trabajo infantil, un objetivo a nuestro alcance. Conferencia Internacional del Trabajo, $95^{\circ}$ reunión, Informe I (B), Ginebra.

Organización Internacional para las Migraciones. 2006. Estudio exploratorio sobre trata de personas con fines de explotación sexual en Argentina, Chile y Uruguay. OIM América Latina.

Organización de las Naciones Unidas (ONU). Protocolo para Prevenir, Reprimir y Sancionar la Trata de Personas, especialmente Mujeres y Niños (Protocolo de Palermo).

ILO. 1930. "Convention Concerning Forced or Compulsory Labour.”

Pecheny, Mario et al. 2019. "Sexual activism and 'actually existing erotism': the politics of victimization and 'lynching' in Argentina.” International Sociology 34(4): 455-470.

Pedraza Gómez, Zandra. 2007. "El trabajo infantil en clave colonial, consideraciones histórico-antropológicas.” Pp. 80-90 in en Revista Nómadas, núm. 2. Colombia: Universidad Central Bogotá.

Sachs, Jeffrey. 2005. O fim da pobreza. Portugal: Casa das Letras.

Santos, Boaventura de S. y Meneses, M.P. (comp). 2014. Epistemologías del Sur: per- 
spectivas. Madrid: Akal.

Sassen, Saskia. 2015. Expulsiones: brutalidad y complejidad en la economía global. Buenos Aires: Katz Editores.

Segato, Rita. 2006. "Antropologia e direitos humanos: alteridade e ética no movimiento de expansao dos direitos universais." Pp. 207-236 in Mana, Universidad Federal de Rio de Janeiro, núm. 12.

Schiavoni, Lidia. 2003. Pesadas cargas, frágiles pasos. Transacciones comerciales en un mercado de frontera. Editorial Universitaria, Universidad Nacional de Misiones.

Unicef. 2005. Situación de la Niñez y de la Adolescencia en la Triple Frontera entre Argentina, Brasil y Paraguay: Desafíos y recomendaciones. Curitiba, Brasil: Unicef.

Quijano, Aníbal. 2000. "Colonialidad del poder, eurocentrismo y América Latina" en.

Van Dick, Teun A. 1995. "Aims of critical discourse analysis.” Pp 17-27 in Japanese discourse.

Wallerstein, Immanuel. 1992. The Modern World-System I: Capitalist Agriculture and the Origins of the European World-Economy in the Sixteenth Century. New York: Academic Press.

\section{BIOGRAPHICAL NOTE}

Maria Cecilia Zsögön, $\mathrm{PhD}$, is a lecturer at the University of Buenos Aires, Argentina. She is interested in gender equality and children's rights.

OPEN ACCESS: This article is distributed under the terms of the Creative Commons Attribution Non-commercial License (CC BY-NC 4.0) which permits any non-commercial use, and reproduction in any medium, provided the original author(s) and source are credited.

ARTICLE HISTORY: Received 2019-09-30 / Accepted 2019-11-29 